consciousness of being a dutiful son; one of a family remarkable for sweetness of disposition and manners, he had lived with his brothers and sisters in terms of mutual love and attachment. He had never lost a friend but by the stroke of mortality, and he felt himself worthy of that constancy of regard. He had followed a profession altogether to his taste, and had followed it in a manner, and with a success which procured him the esteem and respect of all competent judges, and set his name among the most eminent, and he was conscious that his reputation was not unmerited; and with a success, in respect of emolument, which secured the respect even of the ignorant; which gave him the command of every rational gratification, and enabled him to add greatly to the comforts of the numerous descendants of his worthy parents-heirs not only of their name, but likewise of their unambitious moderation and amiable simplicity of character."

Such was Dr. Black as described by those who knew him intimately. We at a greater distance from him can, perhaps, more accurately estimate the character and value of his work. This may be considered under the heads of his three great discoveries. I. The nature of the difference between the mild and the caustic alkalies; 2 . The latent heat of liquids; 3 . The latent heat of vapours.

As a student of medicine in this University his attention was early drawn to the chemical characters of caustic potash and caustic soda, the merits of which as remedies in cases of urinary calculus were then much discussed.

Two kinds of alkalies, the caustic and the mild, had long been distinguished. The former act in a burning, caustic, destructive way on animal and vegetable tissues, the latter do not; the latter effervesce when mixed with acids, the former do not; the former are typified by quick or in slaked lime, the latter by chalk or calcareous earth. Previous to Dr. Black's experiments the difference was thus explained:-When calcareous earth is burnt it becomes quick-lime by taking up from the fite a fiery, caustic matter; some of this is given off as heat when lime is slaked, but some of it remains and gives the causticity by which slaked lime is distinguished from calcareous earth. This causticity is transferred (because the caustic matter is transferred) from the lime to other alkalies. Thus, when slaked lime is mixed with a solution of potashes we obtain caustic potash and the lime becomes mild, is re-transformed into calcareous earth, having parted with its causticum to the potash. Similarly when sal ammoniac is heated with calcareous earth we obtain sal volatile; but whien we act on sal ammoniac with slaked lime the causticum passes from the lime to the volatile alkali and caustic ammonia is produced. In all these cases the caustic matter or causticum originally obtained from the fire was believed to be transferred from one alkali to another. The effervescence which occurs when a "mild alkali" is treated with an acid was of course observed, but it was looked upon merely as a symptom of the violent movements caused by the mutual saturation of acid and alkali.

When slaked lime is exposed to the air it gradually returns to the condition of calcareous earth. On the hypothesis stated above, it must therefore gradually give off its causticum into the air. Black's first experiment seems to have been an attempt to catch the cansticum as it escaped. We have no details of these early experiments, but from a note-book which can be shown to be of the date I752 Dr. Robison extracts the following statement of the result:- "Nothing is given off, the cup rises considerably by absorbing air." Another memorandum occurs a little later: "When I precipitate lime by a common alkali, there is no effervescence. The air quits the alkali for the lime, but it is not lime any longer, but C.C.C. It now effervesces, which good lime will not."

A full account of his experiments and conclusions is contained in his graduation thesis (1754), and in a more extended form in 1756 in "Essays and Observations, Physical and Literary, read before a Society in Edinburgh"-the society which afterwards became the Royal Society of Edinburgh. In this classical paper he shows in the clearest manner that the mild alkalies differ from the caustic by containing in addition a large quantity of "fixed air," a particular kind of gas, which we now know as carbonic acid gas. This gas is given off, causing effervescence when the mild alkali is dissolved in an acid, and the caustic alkali does not effervesce because it does not contain fixed air. Wherever causticity is acquired this fixed air is lost, and vice versâ. When slaked lime is mixed with a mild alkali the lime takes the fixed air, and is converted into calcareous earth, while the mild alkali by the loss of fixed air is rendered caustic. In the same way sal ammoniac with calcareous earth gives a mild volatile alkali, the fixed air being transferred from the lime to the ammonia, but with slaked lime a caustic ammonia, because there is here no fixed air to be transferred. The origin of the causticity in the lime is shown to be due to the loss of fixed air which the heat separates from the limestone, and the loss of weight which is observed when limestone is burnt is shown to be exactly accounted for by the loss of the fixed air. Thus Black proved the "causticum" to be menus fixed air. Addition or subtraction of the former is really subtraction or addition of the latter, and transference of causticum from $A$ to $B$ is really a transference of fixed air from $B$ to $A$.

It is impossible to look at such a sketch of this part of Black's work without being struck with the resemblance between the theory of causticity which he overthrew, the nature of the truth which he discovered, and the method by which he discovered it, on the one hand, and on the other the theory of Phlogiston, the true nature of combustion, and the method by which it was discovered by Lavoisier ; indeed, Lavoisier himself, in a letter to Blach, speaks of the new chemistry as "Une carrière que vous avez ouverte, et dans laquelle nous nous regardons tous comme ros disciples."

The discovery of the latent heat of liquefaction and of vaporisation, was made by Dr. Black while professor in Glasgow. I have occupied so much time with the purely chemical part of my subject that I shall only here point out: (I) That Black's determination of the latent heat of water agrees very closely with the most recent results of experiments conducted with all the refinements of modern science ; (2) That he studied the fusion and solidification of bodies, such as resin and sealing wax, which pass gradudilly from the liquid to the solid state, or vice vers $\hat{a}$; and (3) That it was his teaching which induced Watt to commence the series of experiments and speculations which led to the discovery of the dependence of the latent heat of steam upon the temperature, and to the invention of the condensing steam-engine.

\section{A SCHOOL LABORATORY}

FACTS, not theories. This is the special point in the recent "Head Masters' Report" on science teaching, and, by his interesting account of it in NATURE, rol xil. p. $317, \mathrm{Mr}$. Tuckwell has afforded some opportunity of counting the cost to head-masters projecting a development of their science side, but apparently the Report gives no detail, and it is in this direction, perhaps, that many seek chiefly for information; they would like to know more fully what facilities may be obtained for a particular outlay.

In the hope of giving reliable information of this sort I submit the following particulars:-

The governors of Exeter School, hoping to rekindle the torch of science, lately so unhappily extinguished in the West by the Taunton College authorities, have recently 
erected a chemical laboratory ; it is intended for temporary use indeed, but affords facilities for school work almost rivalling those of the most costly appliances on Mr. Tuckwell's list, and at an expense not much greater than that of the cheapest ; in fact, it has been arranged on a plan based upon experience of the two schools in question. I have said it is intended for temporary use ; I do not mean that it is not calculated for a fair term of service; it is temporary because the present location of the school is not a permanent one.

Abutting a stone wall to feet high, there is built a room 30 feet by 26 feet, and about 16 feet to the ridge of the roof; it is lighted by skylights on each slope of the roof, and the remainder of the roof is boarded and felted. The building is of timber, floor of wood, and about 9 inches above the ground. The bare building thus described cost 88l. The interior arrangements are as shown by the accompanying plan :-

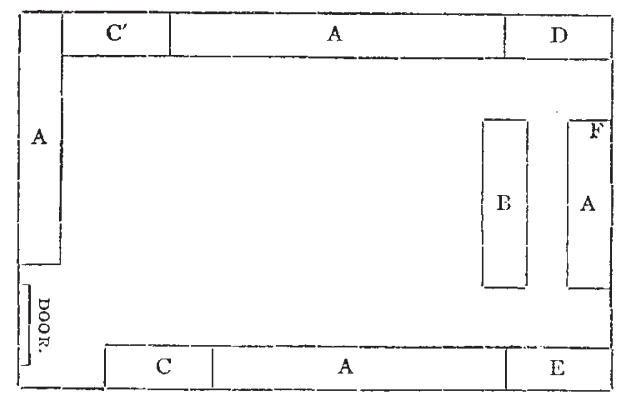

A A A A are working-benches giving accommodation for a class of eighteen or twenty at practical chemistry.

They are of $\mathrm{I}_{2}^{\frac{1}{2}}$ inch deal, supported on tressels 33 inches above the floor and are 25 inches broad, with an under-bench for holding apparatus, and with three shelves in front of them; these are 6 to 9 inches deep, the lowest hold reagent bottles, the next exercises for analysis, and the top shelves are devoted to lecture apparatus when out of use. They are 14, 30, 48 inches above the bench.

r, a lecture-table; its top is 12 feet long, 27 inches broad, I $\frac{1}{2}$ inch thick, beneath are arranged drawers and shelves; it stands 3 feet above the ground. There are two supplies of gas, one about the centre of the table, fitted with three taps, to which Bunsen burners are attached, another of much larger climensions, for supplying a combustion furnace, which does double duty, for warming in very cold weather and lccture purposes at other times.

$\mathrm{C} \mathrm{C}^{\prime}$ are two slate sinks; $\mathrm{C}$ is 39 by $2 \mathrm{I}$ inches, and 6 inches deep, with three taps for water; $C^{\prime}$ is 32 by $2 I$ inches, and 6 inches deep, with two taps; the tops of the sinks are about 2 inches above the level of the workingbenches, and a third tap to $C^{\prime}$ serves to supply the condenser of a still.

$D$ is a fume closet 51 inches long, 23 inches deep, and 64 inches high; it is ventilated by a zinc flue about 6 feet high, under which a jet of gas is burnt when necessary; its doors are 4 feet high and glazed, and the roof slants back from the top of this to the wall.

$\mathrm{E}$.is a cupboard 48 inches long, 26 inches deep, 75 inches high, with glass doors ; inside are shelves arranged for holding apparatus likely to be damaged by the atmosphere of the laboratory. This and the fume-closet are made fairly substantially of deal and are painted or stained. Except the front, back, and sides of the lecturetable, which also are stained and varnished, all other wood-work is left bare.

Beneath B is another cupboard of plain deal, for chemicals, \&c. ; it is 33 inches high measuring from the ground.

Gas is supplied to the working benches by I 7 jets from a $\mathrm{I}$-inch pipe, which is carried a few inches above the top of the bench round the room; the lecture-table, and a pendant with four burners for lighting purposes, are supplied by branches from this, and a third branch supplies the fume-closet.

There is a water-tap at $\mathrm{F}$ for lecture purposes, but no $\operatorname{sink}$.

The cost of these fittings is as follows:-For gas and water fittings (the gas meter is a hired one), $21.145 .7 d$. ; for woodwork and sinks without water fittings, $5 \mathrm{I} l .3 s .3 d$. They are all fairly substantially made, as it is intended to move them to the laboratory to be built at the new school. This sum includes lecturer's desk and stool, waste boxes, \&c. \&c.

The apparatus and chemicals include a Ruhmkorff coil by Apps, giving $\frac{3}{4}$ in. spark, combustion furnace, automatic copper-still, $8 \mathrm{lbs}$. mercury with suitable vessel for keeping it dry and "pure under oil of vitriol, Becker's balance turning to $\frac{1}{10}$ grain, ozone generator, Bunsen's cells, fourteen doz. stoppered reagent bottles, about six or eight doz. bottles for holding solids and solutions for analysis, two doz. 5-pint stoppered bottles for holding stocks of solutions, blowpipe with Fletcher's bellows; a supply of Bunsen's burners, test-tubes, racks, chemicals, and all the other indispensables of a laboratory.

These cost, including carriage by rail, \&c., somewhat under $47 l$, which sum will serve for our wants during the first six months' work.

The total cost amounts to 207l. 17s. rod., to which we add about rol., not more, for some office expenses. For this sum we have a combined laboratory and lectureroom, which is calculated to be sufficiently capacious to afford instruction in theoretical chemistry to 70 per cent. of a school of 150 or 160 boys, and in practical chemistry to about 25 per cent. of the same number; also to serve as an occasional class-room for another science subject.

There is nothing handsome about this laboratory; externally it is tarred, and in summer it will be whitewashed; inside it is chiefly innocent of paint, and its walls are unplaned; but for real work there is very little wạnting.

W. A. SHENSTONE

\section{A NEIV DEEP-SEA THERMOMETER}

THE most efficient deep-sea thermometer constructed up to the present has been the one known as Six's thermometer, with the bulb protected from pressure, as invented by Messrs. Negretti and Zambra, and described in NATURE, vol. ix. p. 387 . This instrument has been extensively used by the expeditions sent out by various governments and scientific societies.

The disadvantages in the old instrument were the following:- $-\mathrm{r}$. The indices were, to a certain extent, unreliable, as, however carefully fitted, they were apt to slip down through their own weight, so that the observations were always more or less doubtful ; 2. Its accuracy, even in its most perfect condition, did not altain to fractions of a clegree, the closest readings differing at least half a degree; 3 . The instrument had always to be carried in a vertical position, or it would become consider. ably deranged. As long as it was sufficient to obtain temperatures varying not less than a degree from one another the old instrument answered tolerably well in deep seas. Recently, however, the bottom temperatures of shallow seas and rivers have come uncler investigation, and for that purpose the instrument proved unsuitable.

The difference between the temperature at the surface of the sea and that at the depth of a few fathoms does not amount to a whole clegree, as a rule, but only to fractions of a degree; hence the observations, to be of any value at all, must be made with an undoubtedly accurate and delicate thermometer. The investigation of the temperatures of the British seas has been urged upon the Government by naturalists and physicists interested in the question of the food supply of the people in its relation to fisheries. The questions of greatest importance were those regarding the influence of temperature upon the habits and migrations of fish, and the determination of the best seasons and temperatures for the development and capture of the various species. This investigation, commenced with the old instrument, has at present only shown that such instruments are not suffi. 